\title{
Role of leptin and melanocortin signaling in uremia-associated cachexia
}

\author{
Wai Cheung, ${ }^{1}$ Pin X. Yu, ${ }^{1}$ Brian M. Little, ${ }^{1}$ Roger D. Cone, ${ }^{2}$ Daniel L. Marks, ${ }^{1}$ and Robert H. Mak ${ }^{1}$ \\ ${ }^{1}$ Department of Pediatrics and ${ }^{2}$ Vollum Institute, Oregon Health and Science University, Portland, Oregon, USA.
}

\begin{abstract}
The pathogenesis of cachexia in patients with uremia is unknown. We tested the hypothesis that uremia-associated cachexia is caused by leptin signaling through the hypothalamic melanocortin receptor 4 (MC4-R). We performed either subtotal nephrectomy $(\mathrm{N})$ or sham operations in WT, leptin receptor-deficient $(d b / d b)$, and MC4-R knockout (MC4-RKO) mice. The animals were on $17 \%$ protein diets, and none of the uremic animals were acidotic. WT-N mice produced a classic syndrome of cachexia characterized by decreased food intake, increased metabolic rate, and loss of lean body mass. Corrected leptin levels were elevated. $d b / d b$ mice and MC4-RKO mice resisted the cachexic effects of uremia on weight gain, body composition, and metabolic rate. Likewise, treatment of WT mice with intracranial agouti-related peptide reversed the cachexic effects of uremia on appetite, weight gain, body composition, and metabolic rate. Gene expression of ubiquitin $\mathrm{C}$ and proteasome subunits C2, C3, and C9 was not changed in the uremic animals, suggesting that other pathways are involved in this model of nonacidotic uremic cachexia. The results of this study suggest that elevated circulating levels of cytokines such as leptin may be an important cause of uremia-associated cachexia via signaling through the central melanocortin system.
\end{abstract}

\section{Introduction}

Cachexia is common in patients with chronic illnesses such as uremia and correlates with quality of life as well as mortality and morbidity in these patients (1). The pathogenesis of cachexia in uremic patients is multifactorial. Recent literature suggests that chronic inflammation is an important cause $(1,2)$. Proinflammatory cytokines play an important role in the pathogenesis of cachexia in acute and chronic disease (3). Leptin is a member of the IL-6 superfamily of cytokines (4). Leptin is increased by both central and systemic immunological challenge and is also a potential mediator of inflammation-induced anorexia $(5,6)$. Circulating leptin is cleared by the kidney, and its concentration is increased in uremia (7). Leptin is taken up into the CNS by a saturable transport system and binds to the long form of the leptin receptor, which is principally located in the arcuate nucleus of the hypothalamus (8). Recent findings suggest that leptin may mediate cachexia by regulating food intake and energy consumption via signaling through the hypothalamic melanocortin system (9).

The hypothalamic melanocortin system is an essential regulator of food intake and energy homeostasis (10). Pro-opiomelanocortin (POMC) is a propeptide precursor that is produced in neurons found in the hypothalamic arcuate nucleus $(10,11)$. POMC neurons are thought to provide an important tonic inhibition of food intake and energy storage, primarily via production and release of $\alpha$-melanocyte-stimulating hormone $(\alpha-\mathrm{MSH})$, which is derived from the POMC precursor. $\alpha$-MSH binds to melanocortin receptors 3 and 4 (MC3-R and MC4-R) and inhibits food intake, primarily via MC4-R (12). Central administration of MC4-R agonists

Nonstandard abbreviations used: AGRP, agouti-related peptide; BUN, blood urea nitrogen; $d b / d b$, leptin receptor-deficient; DEXA, dual-energy X-ray; MC3-R, melanocortin receptor 3; MC4-RKO, MC4-R knockout; MSH, melanocyte-stimulating hormone; N, nephrectomy, nephrectomized; NPY, neuropeptide Y; POMC, pro-opiomelanocortin; S, sham, sham-treated.

Conflict of interest: The authors have declared that no conflict of interest exists.

Citation for this article: J. Clin. Invest. 115:1659-1665 (2005).

doi:10.1172/JCI22521. inhibit energy intake, increase energy expenditure, and reduce body weight $(13,14)$. In contrast, disruption of melanocortin signaling in MC4-R knockout (MC4-RKO) mice leads to an increase in feeding and eventually to overgrowth and obesity $(15,16)$. Agouti-related peptide (AGRP) is an endogenous antagonist of MC3-R and MC4-R $(13,14)$. AGRP is expressed in high levels in the arcuate nucleus of the hypothalamus and projects to many of the same sites to which the agonist-containing POMC neurons project. The expression of AGRP is stimulated by fasting and inhibited by leptin and cytokines $(17,18)$. Furthermore, AGRP is robustly regulated in other animal models of energy imbalance, and its anatomical distribution and function make it a logical candidate for transduction of anorexic signals during both acute and chronic illness. Chronic treatment with AGRP increases food intake, fat mass, and plasma leptin (19). Other important neuropeptides, such as neuropeptide Y (NPY) and ghrelin, have been described, but their role in cytokine-induced cachexia states has not been firmly established (19-21). Although data have been published regarding the circulating concentrations of $\alpha$-MSH (22), NPY (23), and ghrelin (24) in patients with endstage renal disease, the role of this central signaling system in the pathogenesis of cachexia is unknown.

Previous investigators demonstrated that animals with cancer frequently die from cachexia and exhaustion of metabolic fuels. Recently, the role of melanocortin receptors in transducing the prolonged metabolic derangement in experimental cancer was studied. It was demonstrated that the cachexia induced by cancer can be both reversed and prevented by the administration of AGRP (25). Prevention of tumor-induced anorexia with early and repeated AGRP injections resulted in maintenance of normal food intake. To further demonstrate that central melanocortin blockade attenuates cancer cachexia, the response of MC4-RKO mice to experimental cancer was studied. These MC4-RKO rodents had normal feeding and growth, even when bearing a carcinoma that produced classic cachexia in control animals. These data clearly indicate that hypothalamic MC4-R plays an important role in transducing cachexigenic signals from the periphery $(25,26)$. 
Table 1

Serum chemistry of studied mice

\begin{tabular}{|c|c|c|c|c|c|c|}
\hline & $\begin{array}{l}\text { Initial body } \\
\text { weight (g) }\end{array}$ & $\begin{array}{c}\text { Serum } \\
\text { BUN (mg/dl) }\end{array}$ & $\begin{array}{c}\text { Serum } \\
\text { creatinine }(\mathrm{mg} / \mathrm{dl})\end{array}$ & $\begin{array}{l}\text { Bicarbonate } \\
(\mathrm{mmol} / \mathrm{l})\end{array}$ & $\begin{array}{c}\text { Serum } \\
\text { leptin }(\mathrm{ng} / \mathrm{ml})\end{array}$ & $\begin{array}{l}\text { Adjusted serum } \\
\text { leptin (ng/ml) }\end{array}$ \\
\hline WT-N $(n=30)$ & $25.0 \pm 2.0$ & $61.9 \pm 8.9^{A}$ & $0.48 \pm 0.1^{\mathrm{A}}$ & $26.1 \pm 0.9$ & $6.40 \pm 1.14$ & $3.37 \pm 0.66^{\mathrm{A}}$ \\
\hline WT-S $(n=30)$ & $24.1 \pm 1.8$ & $30.4 \pm 4.7$ & $0.26 \pm 0.1$ & $26.2 \pm 1.5$ & $6.16 \pm 1.08$ & $2.22 \pm 0.33$ \\
\hline$d b / d b-\mathrm{N}(n=6)$ & $32.6 \pm 0.8$ & $60.7 \pm 9.1^{A}$ & $0.57 \pm 0.1^{A}$ & $25.5 \pm 0.6$ & $31.96 \pm 4.21^{\mathrm{A}}$ & $1.35 \pm 0.18$ \\
\hline$d b / d b-S(n=6)$ & $33.4 \pm 1.2$ & $32.3 \pm 5.7$ & $0.22 \pm 0.1$ & $25.1 \pm 0.4$ & $21.17 \pm 4.28$ & $1.30 \pm 0.34$ \\
\hline MC4-RKO-/--N $(n=15)$ & $29.5 \pm 0.8$ & $47.7 \pm 5.0^{\mathrm{A}}$ & $0.44 \pm 0.1^{B}$ & $25.7 \pm 0.6$ & $11.73 \pm 3.13^{B}$ & $2.66 \pm 0.63^{B}$ \\
\hline MC4-RKO-/-S $(n=16)$ & $29.2 \pm 1.2$ & $29.6 \pm 4.8$ & $0.26 \pm 0.1$ & $26.4 \pm 1.2$ & $9.65 \pm 0.32$ & $1.94 \pm 0.25$ \\
\hline MC4-RKO+/--N $(n=7)$ & $32.8 \pm 1.5$ & $59.3 \pm 9.8^{B}$ & $0.60 \pm 0.1^{B}$ & $24.8 \pm 1.1$ & $9.07 \pm 1.85$ & $2.43 \pm 0.42^{B}$ \\
\hline MC4-RKO+/-S $(n=7)$ & $33.2 \pm 1.2$ & $33.7 \pm 5.4$ & $0.29 \pm 0.1$ & $25.0 \pm 0.4$ & $7.95 \pm 1.33$ & $1.87 \pm 0.31$ \\
\hline WT-N/AGRP $(n=14)$ & $25.2 \pm 1.4$ & $58.4 \pm 9.2^{\mathrm{A}}$ & $0.49 \pm 0.1^{A}$ & $24.9 \pm 1.7$ & $5.15 \pm 0.72$ & $2.42 \pm 0.76$ \\
\hline WT-N $(n=14)$ & $24.4 \pm 2.3$ & $54.1 \pm 6.3^{\mathrm{A}}$ & $0.49 \pm 0.1^{A}$ & $25.4 \pm 2.4$ & $6.78 \pm 1.33^{B}$ & $3.56 \pm 0.96 \mathrm{~A}$ \\
\hline WT-S $(n=14)$ & $25.8 \pm 3.2$ & $29.1 \pm 8.1$ & $0.26 \pm 0.1$ & $25.7 \pm 2.1$ & $5.22 \pm 0.84$ & $2.21 \pm 0.37$ \\
\hline
\end{tabular}

Animals were sacrificed at the end of 14 days. Eleven groups of animals were compared: WT-N versus WT-S; $d b / d b-\mathrm{N}$ versus $d b / d b-\mathrm{S}$; MC4-RKO----N versus MC4-RKO----S; MC4-RKO+/--N versus MC4-RKO+/--S; and WT-N/AGRP and WT-N versus WT-S. Adjusted serum leptin is calculated as serum leptin level $(\mathrm{ng} / \mathrm{ml})$ divided by final fat mass $(\%)$. Data are expressed as means \pm SD. ${ }^{A} P<0.0001 .{ }^{B} P<0.005$.

The central hypothesis of this study is that elevated proinflammatory cytokines such as leptin play an important part in the pathogenesis of uremia-associated cachexia through the hypothalamic melanocortin signaling pathway. We found that uremia-associated cachexia was attenuated in leptin receptordeficient $(d b / d b)$ mice as well as in MC4-RKO mice, and that the same result was also obtained by pharmacological (AGRP) blockade of the MC4-R.

\section{Results}

Cachexia in nephrectomized WT mice. Our data indicate that nephrectomized WT (WT-N) mice, fed on $17 \%$ protein diets, were uremic but not acidotic. WT-N mice had higher levels of blood urea nitrogen $(\mathrm{BUN})$ and creatinine $(61.9 \pm 8.9 \mathrm{mg} / \mathrm{dl}$ and $0.48 \pm 0.1 \mathrm{mg} / \mathrm{dl}$, respectively; $n=30$ ) than WT sham (WT-S) control mice $(30.4 \pm 4.7 \mathrm{mg} / \mathrm{dl}$ and $0.26 \pm 0.1 \mathrm{mg} / \mathrm{dl}$, respectively; $n=30 ; P<0.0001$; Table 1$)$. Blood bicarbonate levels were not different in WT-N mice $(26.1 \pm 0.9 \mathrm{mmol} / \mathrm{l})$ and WT-S mice $(26.2 \pm 1.5 \mathrm{mmol} / \mathrm{l}$; Table 1$)$, which indicates that WT-N mice were not acidotic when sacrificed. Adjusted serum leptin levels were elevated in WT-N mice (3.37 \pm 0.66 $\mathrm{ng} / \mathrm{ml})$ compared with those in WT-S mice $(2.22 \pm 0.33 \mathrm{ng} / \mathrm{ml}$; $P<0.0001$; Table 1).

WT-N mice were fed ad libitum with powdered food $(55.11 \pm 6.84 \mathrm{~g})$ containing $17 \%$ protein, whereas WT-S mice were pair-fed (54.86 $\pm 6.62 \mathrm{~g}$; Figure $1 \mathrm{~A})$. WT-N mice were cachexic. WT-N mice gained less weight (gain of $0.51 \pm 0.24 \mathrm{~g}$ ) compared with pair-fed WT-S mice (gain of $1.23 \pm 0.35 \mathrm{~g} ; P<0.001$; Figure 1B). WT-N mice continued to lose lean body mass and

\section{Figure 1}

Cumulative food consumption ( $\mathbf{A}$ and $\mathbf{C}$ ) and cumulative weight gain ( $\mathbf{B}$ and $\mathbf{D}$ ) during a 14-day study. Pair-feeding animal groups: WT-N mice were fed ad libitum; $d b / d b-\mathrm{N}$ mice were pair-fed with the WT-N mice; MC4-RKO-/--N mice were fed ad libitum; $\mathrm{MC}^{-}-\mathrm{RKO}^{+/-}-\mathrm{N}$ were pair-fed with the WT-N mice. All the S control animals were pair-fed with respective $\mathrm{N}$ mice. Non-pair-feeding animal groups: WT-N/AGRP and WT-N mice were fed ad libitum, whereas WT-S mice were pair-fed with WT-N/AGRP mice. Data are expressed as means \pm SD. fat mass (losses of $6.0 \% \pm 1.5 \%$ and $15.8 \% \pm 5.3 \%$, respectively), whereas WT-S mice gained lean body mass and fat mass (gains of $4.9 \% \pm 2.1 \%$ and $11.8 \% \pm 3.0 \%$, respectively; $P<0.001$; Figure $2, \mathrm{~A}$ and $\mathrm{B}$ ). Resting metabolic ratewas increased in WT-Nmice $(2697 \pm 173 \mathrm{ml} / \mathrm{kg} / \mathrm{h})$ versus that in WT-S mice $(2404 \pm 174 \mathrm{ml} / \mathrm{kg} / \mathrm{h} ; P<0.001$; Figure $3 \mathrm{~A})$. Conversely, efficiency of food consumption (calculated as the cumulative weight gain [in grams] divided by total food consumption [in grams]) was decreased in WT-N mice $(0.009 \pm 0.005)$ compared with that in pair-fed WT-S mice $(0.023 \pm 0.008 ; P<0.001$; Figure $3 \mathrm{~B})$.
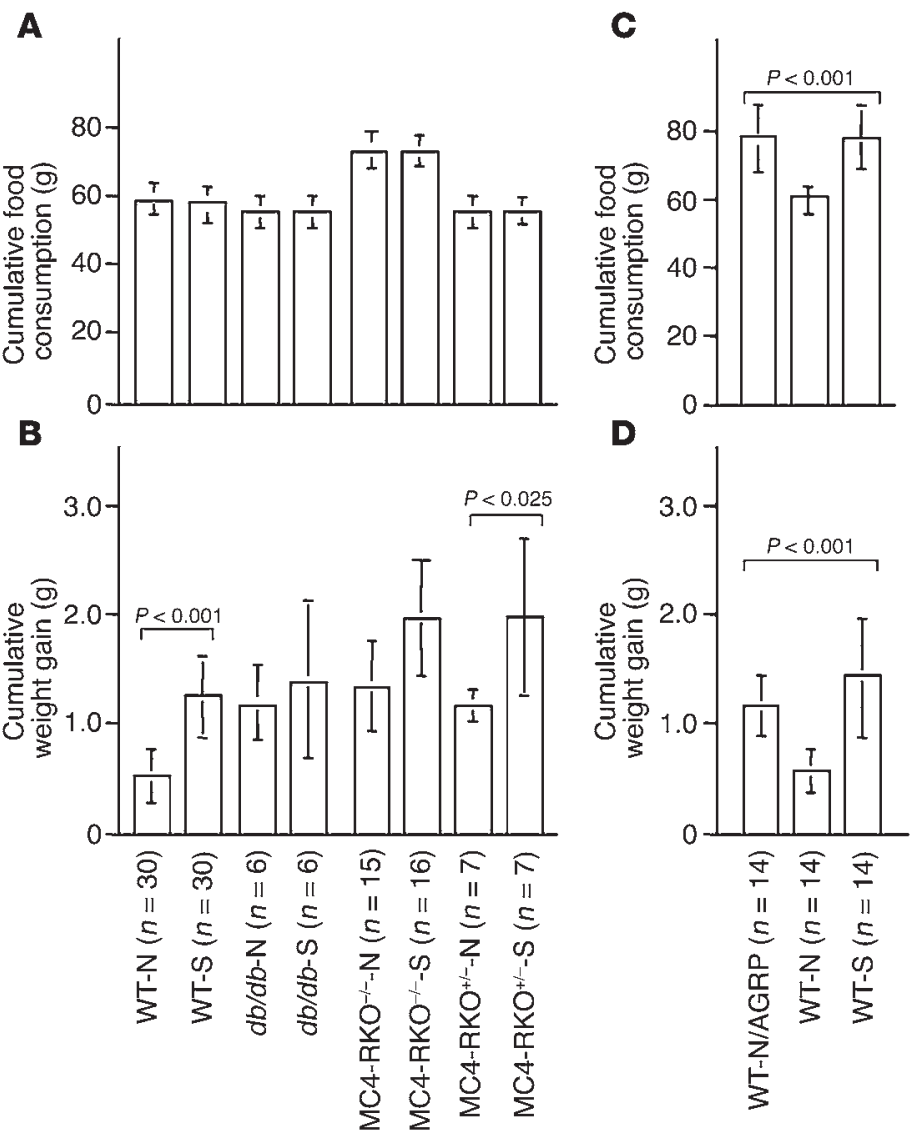

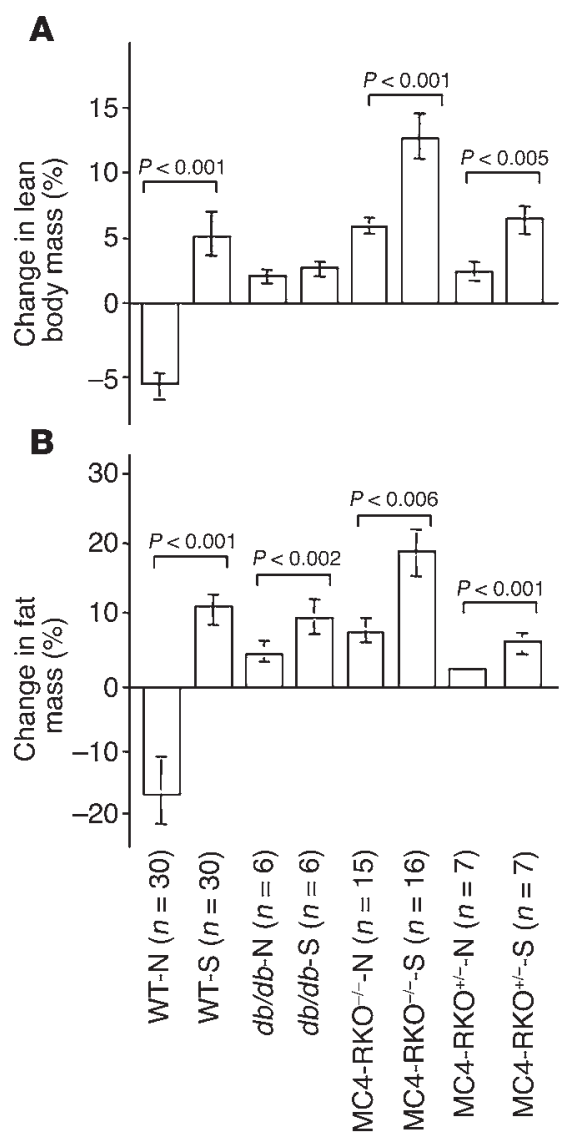

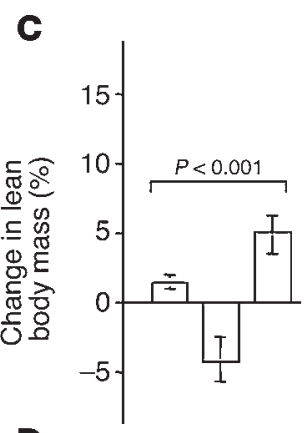

D

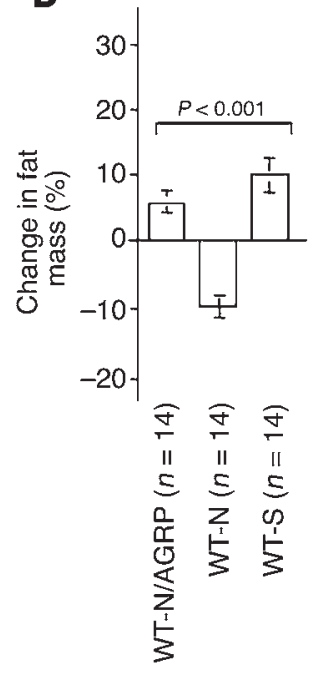

Figure 2

Experimental mice were scanned by DEXA to determine the change in lean body mass ( $\mathbf{A}$ and $\mathbf{C}$ ) and fat mass ( $\mathbf{B}$ and $\mathbf{D})$. Animals were scanned 1 day prior to the starting of the experiment, followed 14 days later by a second DEXA scan. Final results as percent change from baseline are expressed as means \pm SD.

$d b / d b$ mice resist $N$-induced uremic cachexia. Leptin may mediate cachexia in uremia by first binding to its own receptor. The effect of leptin receptor blockade in the pathological development of uremic cachexia was tested via a genetic approach. Both $d b / d b-\mathrm{N}$ $(n=6)$ and $d b / d b$-S mice $(n=6)$ were pair-fed with the WT-N mice (Figure 1A). Pair-fed $d b / d b-\mathrm{N}$ mice had higher BUN and creatinine levels $(60.7 \pm 9.1 \mathrm{mg} / \mathrm{dl}$ and $0.57 \pm 0.1 \mathrm{mg} / \mathrm{dl}$, respectively) compared with those in $d b / d b-\mathrm{S}$ mice $(32.3 \pm 5.7 \mathrm{mg} / \mathrm{dl}$ and $0.22 \pm 0.1 \mathrm{mg} / \mathrm{dl}$, respectively; $P<0.0001)$ and were not acidotic (Table 1). Blood bicarbonate levels in $d b / d b-\mathrm{N}$ mice $(25.5 \pm 0.6 \mathrm{mg} / \mathrm{dl})$ were comparable to those in $d b / d b$-S mice $(25.1 \pm 0.4 \mathrm{mg} / \mathrm{dl}$; Table 1$)$. There was no difference in adjusted serum leptin level between $d b / d b-\mathrm{N}$ and $d b / d b$-S mice $(1.35 \pm 0.18 \mathrm{ng} / \mathrm{ml}$ versus $1.30 \pm 0.34 \mathrm{ng} / \mathrm{ml}$; NS; Table 1$)$.

Our results suggested that $d b / d b$ mice resisted $\mathrm{N}$-induced uremic cachexia. Both $d b / d b-\mathrm{N}$ and $d b / d b$-S mice gained weight (gain of $1.14 \pm 0.32$ g versus $1.34 \pm 0.69 \mathrm{~g}$; NS; Figure $1 \mathrm{~B}$ ). There was no difference in lean body mass between $d b / d b-\mathrm{N}$ and $d b / d b$-S mice (gain of $1.9 \% \pm 1.0 \%$ versus $2.6 \% \pm 0.6 \%$; NS). In addition, $d b / d b-\mathrm{N}$ mice gained fat mass (gain of $4.6 \% \pm 1.5 \%$ ), although less than that in $d b / d b$-S mice (gain of $10.0 \% \pm 2.7 \% ; P<0.002$; Figure 2 , A and $\mathrm{B}$ ). There was no difference in resting metabolic rate between $d b / d b-\mathrm{N}$

mice $(2298 \pm 44 \mathrm{ml} / \mathrm{kg} / \mathrm{h})$ and $d b / d b$-S mice $(2271 \pm 101 \mathrm{ml} / \mathrm{kg} / \mathrm{h}$; Figure $3 \mathrm{~A})$. Moreover, there was no difference in efficiency of food consumption between $d b / d b-\mathrm{N}$ and $d b / d b-\mathrm{S}$ mice $(0.022 \pm 0.007$ versus $0.025 \pm 0.013$; NS; Figure 3B).

$M C 4-R K O$ mice resist $N$-induced uremic cachexia. Leptin exerts its hypothalamic effects through MC4-R. The effect of MC4-R blockade in the pathological development of uremic cachexia was therefore tested via a genetic approach. Homozygous MC4-RKO-/- mice were derived and maintained as described (16). Heterozygous $\mathrm{MC}_{-}-\mathrm{RKO}^{+/-}$mice were generated by mating homozygous WT and homozygous MC4-RKO ${ }^{-/-}$mice. MC4-RKO ${ }^{-1-}-\mathrm{N}$ mice $(n=15)$ were fed ad libitum with powdered food $(68.75 \pm 4.37 \mathrm{~g})$, whereas MC4-RKO-/-S mice were pair-fed (69.00 \pm 4.34 g; Figure 1A). $\mathrm{MC}^{-} \mathrm{RKO}^{-/-}-\mathrm{N}$ mice were uremic, as they had higher levels of BUN and creatinine compared with those of pair-fed MC4-RKO-/-S mice(BUN, $47.7 \pm 5.0 \mathrm{mg} /$ dlversus $29.6 \pm 4.8 \mathrm{mg} / \mathrm{dl}$, $P<0.0001$; creatinine, $0.44 \pm 0.1 \mathrm{mg} / \mathrm{dl}$ versus $0.26 \pm 0.1 \mathrm{mg} / \mathrm{dl}$, $P<0.005$; Table 1). MC4-RKO $/--\mathrm{N}$ mice were not acidotic. Blood bicarbonate levels in $\mathrm{MC} 4-\mathrm{RKO}^{-/-} \mathrm{N}$ mice $(25.7 \pm 0.6 \mathrm{mg} / \mathrm{dl})$ were comparable to those in $\mathrm{MC} 4-\mathrm{RKO}^{-/-}$-S mice $(26.4 \pm 1.2 \mathrm{mg} / \mathrm{dl}$; Table 1). Adjusted serum leptin levels were elevated in $\mathrm{MC}^{-} \mathrm{RKO}^{-/-} \mathrm{N}$ mice compared with those in $\mathrm{MC} 4-\mathrm{RKO}^{-/-}-\mathrm{S}$ mice $(2.66 \pm 0.63$ $\mathrm{mg} / \mathrm{dl}$ versus $1.94 \pm 0.25 \mathrm{mg} / \mathrm{dl} ; P<0.005$; Table 1 ).

MC4- $\mathrm{RKO}^{-/-}$mice significantly resisted $\mathrm{N}$-induced uremic cachexia. Both MC4-RKO-/--N and pair-fed MC4-RKO-/--S mice gained weight (gain of $1.30 \pm 0.41$ g versus $1.91 \pm 0.52 \mathrm{~g}$; $\mathrm{NS}$; Figure 1B). MC4-RKO-/--N mice also gained lean body mass and fat mass, although less than did $\mathrm{MC}^{-} \mathrm{RKO}^{-/-}-\mathrm{S}$ mice (lean body mass, gain of $5.6 \% \pm 1.0 \%$ versus $12.4 \% \pm 2.1 \%$, $P<0.001$; fat mass, gain of $7.8 \% \pm 2.4 \%$ versus $20.0 \% \pm 3.8 \%$, $P<0.006$; Figure 2, A and B). Resting metabolic rate was higher in MC4-RKO ${ }^{-/-}-\mathrm{N}$ mice $(2504 \pm 133 \mathrm{ml} / \mathrm{kg} / \mathrm{h})$ than in $\mathrm{MC}^{-}-\mathrm{RKO}^{-/-}-\mathrm{S}$ mice $(2397 \pm 121 \mathrm{ml} / \mathrm{kg} / \mathrm{h} ; P<0.05$; Figure $3 \mathrm{~A})$. However, there was no difference in efficiency of food consumption between $\mathrm{MC}^{-\mathrm{RKO}^{-/-} \mathrm{N} \text { and MC4-RKO}} \mathrm{KO}^{-/-}-\mathrm{S}$ mice $(0.019 \pm 0.006$ versus $0.028 \pm 0.008$; NS; Figure $3 \mathrm{~B}$ ).

Additional experiments in heterozygous $\mathrm{MC}^{-} \mathrm{RKO}^{+/-}$mice were also performed. Both MC4-RKO ${ }^{+--} \mathrm{N}(n=7)$ and $\mathrm{MC}^{-}-\mathrm{RKO}^{+/-}-\mathrm{S}$ $(n=7)$ mice were pair-fed with WT-N mice (Figure 1A). Pair-fed MC4-RKO ${ }^{+/-} \mathrm{N}$ mice had higher BUN and creatinine levels $(59.3 \pm 9.8 \mathrm{mg} / \mathrm{dl}$ and $0.60 \pm 0.1 \mathrm{mg} / \mathrm{dl}$, respectively) compared with those in MC4-RKO ${ }^{+/-}-\mathrm{S}$ mice $(33.7 \pm 5.4 \mathrm{mg} / \mathrm{dl}$ and $0.29 \pm 0.1 \mathrm{mg} / \mathrm{dl}$, respectively; $P<0.005$ ) and were not acidotic (Table 1 ). There was no difference between the blood bicarbonate levels in $\mathrm{MC}^{-}-\mathrm{RKO}^{+/-} \mathrm{N}$ and MC4-RKO ${ }^{+/-}-$S mice $(24.8 \pm 1.1 \mathrm{mmol} / \mathrm{l}$ versus $25.0 \pm 0.4 \mathrm{mmol} / \mathrm{l}$; NS; Table 1). Adjusted serum leptin levels were still higher in MC4-RKO ${ }^{+/-}-\mathrm{N}$ mice $(2.43 \pm 0.42 \mathrm{ng} / \mathrm{ml})$ than in $\mathrm{MC} 4-\mathrm{RKO}^{+/-}-\mathrm{S}$ mice $(1.87 \pm 0.31 \mathrm{ng} / \mathrm{ml} ; P<0.005$; Table 1$)$.

Our results suggest that $\mathrm{MC} 4-\mathrm{RKO}^{+/-}$mice resisted $\mathrm{N}$-induced uremic cachexia. MC4- $\mathrm{RKO}^{+/-}-\mathrm{N}$ mice gained weight, although less than did $\mathrm{MC} 4-\mathrm{RKO}^{+/-}-\mathrm{S}$ mice (gain of $1.13 \pm 0.14$ g versus $1.93 \pm 0.75 \mathrm{~g} ; P<0.025$; Figure $1 \mathrm{~B}$ ). $\mathrm{MC} 4-\mathrm{RKO}^{+/-}-\mathrm{N}$ mice also gained lean body mass and fat mass, although less than did MC4-RKO ${ }^{+/-}-\mathrm{S}$ mice (lean body mass, gain of $2.3 \% \pm 0.6 \%$ versus $6.3 \% \pm 1.6 \%, P<0.005$; fat mass, gain of $2.4 \% \pm 0.6 \%$ versus $6.5 \% \pm 1.3 \%$, $P<0.001$; Figure 2, A and B). There was no difference between the resting metabolic rate in $\mathrm{MC} 4-\mathrm{RKO}^{+/-}-\mathrm{N}$ mice $(2466 \pm 176 \mathrm{ml} / \mathrm{kg} / \mathrm{h})$ and that in MC4-RKO ${ }^{+/-}-\mathrm{S}$ mice $(2522 \pm 71 \mathrm{ml} / \mathrm{kg} / \mathrm{h}$; Figure $3 \mathrm{~A})$. Moreover, there was no difference in efficiency of food consumption 

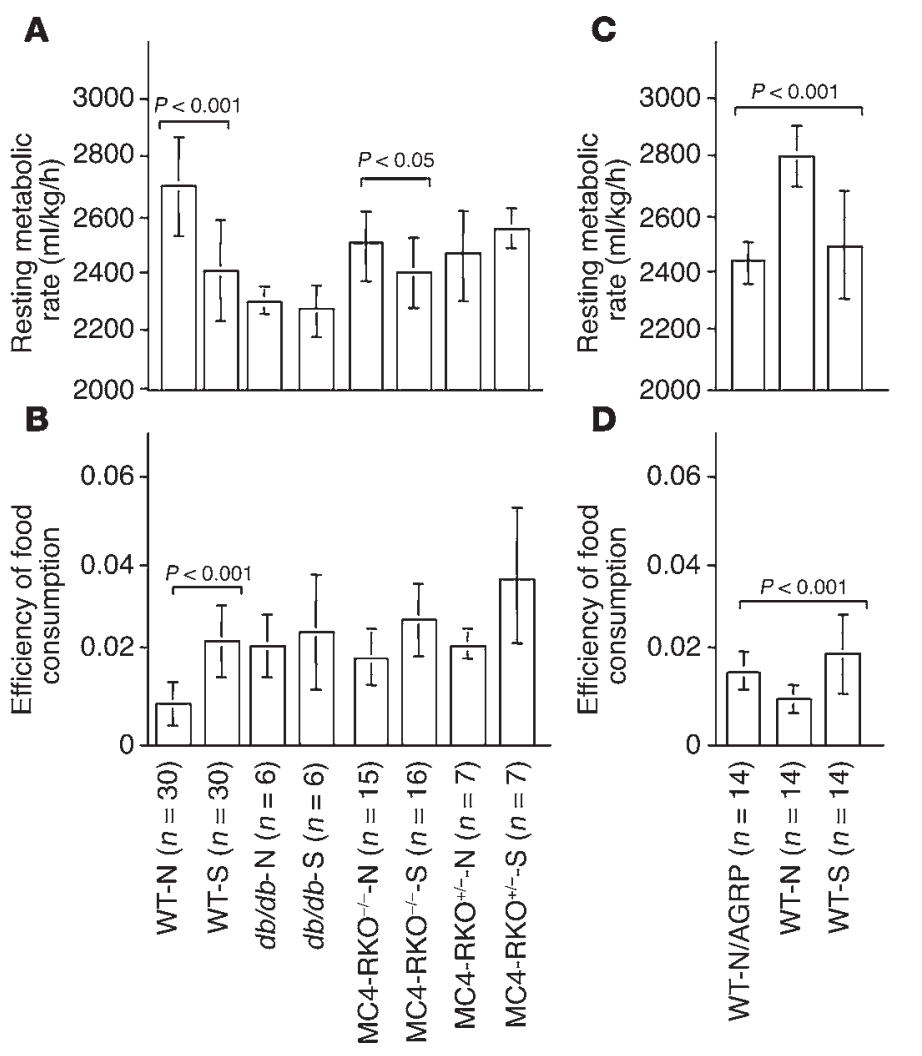

between $\mathrm{MC} 4-\mathrm{RKO}^{+/-}-\mathrm{N}$ and $\mathrm{MC} 4-\mathrm{RKO}^{+/-}-\mathrm{S}$ mice $(0.022 \pm 0.003$ versus $0.037 \pm 0.010$; NS; Figure $3 \mathrm{~B}$ ).

$A G R P$ administration prevents $N$-induced uremic cachexia in WT mice. The effect of melanocortin receptor blockade in our animal model of uremic cachexia was investigated using a pharmacological approach. AGRP, produced in the arcuate nucleus, is an antagonist of MC3-R and MC4-R. We tested response to CNS administration of AGRP in WT-N mice. AGRP-treated WT-N (WT-N/AGRP) and WT-N mice were uremic but not acidotic. WT-N/AGRP $(n=14)$ and WT-N mice $(n=14)$ had higher levels of BUN $(58.4 \pm 9.2 \mathrm{mg} / \mathrm{dl}$ and $54.1 \pm 6.3 \mathrm{mg} / \mathrm{dl}$, respectively) and creatinine $(0.49 \pm 0.1 \mathrm{mg} / \mathrm{dl}$ and $0.49 \pm 0.1 \mathrm{mg} / \mathrm{dl}$, respectively) than did WT-S mice $(29.1 \pm 8.1 \mathrm{mg} / \mathrm{dl}$ and $0.26 \pm 0.1 \mathrm{mg} / \mathrm{dl}$, respectively; $n=14 ; P<0.0001$; Table 1 ). Blood bicarbonate levels were not different in WT-N/AGRP $(24.9 \pm 1.7 \mathrm{mg} / \mathrm{dl})$ and WT-N $(25.4 \pm 2.4 \mathrm{mg} / \mathrm{dl})$ compared with those in WT-S mice $(25.7 \pm 2.1 \mathrm{mg} / \mathrm{dl}$; Table 1$)$. Whereas adjusted serum leptin levels were still high in WT-N mice $(3.56 \pm 0.96$ $\mathrm{ng} / \mathrm{ml} ; P<0.0001)$, administration of AGRP significantly decreased the serum leptin level in the uremic animals. There was no difference between adjusted serum leptin levels in WT-N/AGRP and WT-S mice $(2.42 \pm 0.76 \mathrm{ng} / \mathrm{ml}$ versus $2.21 \pm 0.4 \mathrm{ng} / \mathrm{ml}$; Table 1 ).

Uremic cachexia in subtotal WT-N animals was ameliorated by intracranial administration of AGRP. For this study, WT-N/AGRP and WT-N mice were allowed ad libitum access to the powdered food, whereas WT-S

\section{Table 2}

\section{Figure 3}

Resting metabolic rate (A and $\mathbf{C}$ ) and efficiency of food consumption ( $\mathbf{B}$ and $\mathbf{D}$ ) were measured in experimental animals at the end of the study. Resting metabolic rate $(\mathrm{ml} / \mathrm{kg} / \mathrm{h})$ is calculated as the average of the lowest 3 readings obtained during the recording period. Efficiency of food consumption is calculated as the cumulative weight gain (in grams) divided by total food consumption (in grams). Results are expressed as means \pm SD.

mice were pair-fed with WT-N/AGRP mice. Administration of AGRP increased the daily food intake of WT-N/AGRP mice $(73.35 \pm 9.16 \mathrm{~g})$ compared with that of WT-N mice $(56.99 \pm 3.86 \mathrm{~g}$; $P<0.001$; Figure 1C). WT-N/AGRP mice gained more weight (gain of $1.13 \pm 0.27 \mathrm{~g}$ ) than did WT-N mice (gain of $0.55 \pm 0.20 \mathrm{~g}$ ), although this was less than in the WT-S mice (gain of $1.40 \pm 0.51 \mathrm{~g}$; $P<0.001$; Figure 1D). WT-N/AGRP mice gained lean body mass and fat mass (gains of $1.3 \% \pm 0.6 \%$ and $5.1 \% \pm 1.8 \%$, respectively), although still less than did WT-S mice (gains of $5.2 \% \pm 1.8 \%$ and $9.6 \% \pm 2.6 \%$, respectively), whereas WT-N mice continued to lose lean body mass and fat mass (losses of $4.3 \% \pm 2.1 \%$ and $9.8 \% \pm 2.3 \%$, respectively; $P<0.001$; Figure 2, C and D). Results also demonstrate that AGRP caused decreased energy expenditure. Resting metabolic rate was higher in WT-N mice $(2798 \pm 105 \mathrm{ml} / \mathrm{kg} / \mathrm{h})$ compared with that of WT-N/AGRP and pair-fed WT-S mice $(2439 \pm 97 \mathrm{ml} / \mathrm{kg} / \mathrm{h}$ and $2492 \pm 267 \mathrm{ml} / \mathrm{kg} / \mathrm{h} ; P<0.001$; Figure $3 \mathrm{C}$ ). In addition, both WT-N/AGRP and WT-S mice had higher efficiencies of food consumption $(0.016 \pm 0.004$ and $0.020 \pm 0.009$, respectively) than did WT-N mice $(0.010 \pm 0.003$; $P<0.001$ ) (Figure 3D).

$m R N A$ expression of ATP-dependent ubiquitin-proteasome pathway in $N$-induced uremic cachexia. Muscle mRNA levels for ubiquitin C and proteasome subunits C2, C3, and C9 in 7 groups of experimental animals (i.e., WT-N versus WT-S; MC4RKO-/--N versus $\mathrm{MC}_{\mathrm{RKO}}{ }^{-/-}-\mathrm{S}$; and WT-N/AGRP and WT-N versus WT-S mice) were measured (Table 2). There was no difference in ubiquitin $\mathrm{C}$ mRNA levels in muscles of the uremic mice compared with those of sham controls. Similar results were obtained with cDNA of the proteasome subunits C2, C3, and C9 (Table 2).

\section{Discussion}

Cachexia is characterized by both loss of appetite and an inability to conserve energy (26). The hallmark of the disorder is a significant loss of fat and lean body mass. Interactions among cytokines, peptide/neuropeptides, and neurotransmitters, as well as modifications of signal-transducing and intracellular media-

Ubiquitin C and proteasome subunits C2, C3, and C9 mRNA expression in muscle

$\begin{array}{lcrrr} & \text { Ubiquitin C } & \text { Proteasome C2 } & \text { Proteasome C3 } & \text { Proteasome C9 } \\ \text { WT-N }(n=10) & 1.253 \pm 0.013 & 2.821 \pm 0.019 & 1.117 \pm 0.015 & 0.722 \pm 0.017 \\ \text { WT-S }(n=10) & 1.241 \pm 0.062 & 2.813 \pm 0.017 & 1.121 \pm 0.013 & 0.715 \pm 0.015 \\ \text { MC4-RKO-/-N }(n=10) & 1.239 \pm 0.021 & 2.797 \pm 0.016 & 1.127 \pm 0.016 & 0.753 \pm 0.015 \\ \text { MC4-RKO---S }(n=10) & 1.244 \pm 0.012 & 2.808 \pm 0.013 & 1.131 \pm 0.016 & 0.765 \pm 0.017 \\ \text { WT-N/AGRP }(n=10) & 1.246 \pm 0.011 & 2.823 \pm 0.026 & 1.121 \pm 0.014 & 0.726 \pm 0.021 \\ \text { WT-N }(n=10) & 1.249 \pm 0.017 & 2.831 \pm 0.021 & 1.118 \pm 0.021 & 0.721 \pm 0.009 \\ \text { WT-S }(n=10) & 1.251 \pm 0.013 & 2.829 \pm 0.017 & 1.125 \pm 0.026 & 0.731 \pm 0.027\end{array}$

Seven groups of animals were compared: WT-N versus WT-S; MC4-RKO-/--N versus MC4-RKO-/--S; and WT-N/AGRP and WT-N versus WT-S. Comparative cycle of threshold $\left(\mathrm{C}_{\mathrm{T}}\right)$ method was used to determine the relative quantification of target gene versus $18 \mathrm{~S}$ ribosomal RNA. Data are expressed as means \pm SD. 
tor events in the CNS, may be important for the induction and progression of the cachexia-anorexia syndrome. In this study, we tested the hypothesis that uremic cachexia is caused by increased circulating concentrations of cytokines such as leptin through hypothalamic MC4-R.

All animals used in this study were on the same genetic background (C57BL/6J). In an initial series of experiments, we demonstrated that subtotal $\mathrm{N}$ in WT mice led to reduced food intake (Figure $1 \mathrm{~A}$ ) and weight gain (Figure 1B), loss of lean body mass (Figure 2A) and fat mass (Figure 2B), increased resting metabolic rate (Figure $3 \mathrm{~A}$ ), and reduced efficiency of food consumption (Figure 3B). Circulating leptin level in relation to percentage of body fat mass was greater in WT-N mice compared with that in respective pair-fed WT-S controls (Table 1).

We tested the hypothesis that leptin is an important cause of uremic cachexia via signaling through its receptor. Our results showed that uremic cachexia was attenuated in $d b / d b$ mice, a model of leptin-receptor deficiency. $\mathrm{N}$ in these animals did not result in any change in weight gain (Figure 1B), body composition (Figure 2, $A$ and $B$ ), resting metabolic rate (Figure $3 \mathrm{~A}$ ), or efficiency of food consumption (Figure $3 \mathrm{~B}$ ). Recent studies suggested that $d b / d b$ mice resisted LPS-induced anorexia by reducing TNF- $\alpha$ secretion (27). Thus, leptin may have an important role in the regulation of appetite, body composition, and metabolic rate in uremia. Indeed, elevated serum leptin was associated with lower dietary intake and higher catabolic rate in uremic children (28).

In another set of experiments, we demonstrated that uremic cachexia in experimental animals was attenuated by central MC4-R blockade via a genetic approach. Both homozygous and heterozygous MC4-RKO mice had no decrease in appetite after $\mathrm{N}$ compared with WT-S animals. The most striking difference was that both the homozygous and heterozygous MC4-RKO animals continued to gain lean body mass (Figure 2A) and fat mass (Figure 2B), with no change in the food consumption efficiency (Figure 3B), despite the cachexic effects of uremia shown in the WT-N controls. The effects of $\mathrm{N}$ on increasing resting metabolic rate as demonstrated in the WT animals were also much attenuated in both the homozygous group and the heterozygous group (Figure 3A). Our results are consistent with previous observations that MC4-RKO animals maintained normal metabolic rate and body composition even when bearing a carcinoma that produced classic cachexia in WT control animals (25). These data strongly suggest that hypothalamic MC4-R plays a significant role in transducing cachexigenic signals in uremia.

We then tested the effect of central melanocortin receptor antagonism in the experimental uremic cachexia models using a pharmacological approach. Our data clearly demonstrated that uremic cachexia was ameliorated by central administration of AGRP in WT-N mice. Repeated intracranial infusion of AGRP significantly regulated food intake (Figure 1C), weight gain (Figure 1D), body composition (Figure 2, C and D), resting metabolic rate (Figure $3 \mathrm{C}$ ), efficiency of food consumption (Figure $3 \mathrm{D}$ ), and circulating leptin concentration in WT-N/AGRP mice compared with that in WT-N mice (Table 1). AGRP is an antagonist for MC4-R. Tumor- and sepsis-induced cachexia is attenuated by MC4-R blockade with AGRP (25).

Finally, we investigated whether muscle wasting in our nonacidotic uremic model of cachexia is related to upregulation of mRNA gene expression of the ATP-dependent ubiquitin-proteasome pathway. In muscle, there are at least 4 pathways that can degrade proteins: lysosome, calcium-dependent protease, ATPdependent ubiquitin-proteasome, and ATP-independent pathways (29). The ubiquitin-dependent pathway is principally responsible for increased skeletal muscle degradation (30). In acidotic and cancer cachexic rats, increase in skeletal muscle proteolysis is associated with an increase in the expression of genes for ubiquitin and proteasome subunits (31-33). We measured the mRNA levels of ubiquitin $\mathrm{C}$ and proteasome subunits C2, C3, and C9 in 7 experimental groups and did not find any difference (Table 2). Mitch and coworkers demonstrated significantly increased expression of the ubiquitin gene and 2 genes for proteasome subunits in uremic rats on a very high protein diet $(46 \%)$, resulting in profound uremia (mean BUN level, $140 \mathrm{mg} / \mathrm{dl}$ ) and metabolic acidosis (mean serum bicarbonate level, $8 \mathrm{mg} / \mathrm{dl}$ ) (29). Our uremic mice were on a lower protein diet $(17 \%)$ and were consequently less uremic (mean BUN level of all groups examined, $62 \mathrm{mg} / \mathrm{dl}$ ) and not acidotic (mean serum bicarbonate level, $25 \mathrm{mg} / \mathrm{dl}$ ). This may explain why we did not observe the mRNA changes in ubiquitin and proteasome subunits. Although ATP-dependent ubiquitin-proteasome proteolysis is an important cause of muscle wasting in uremic rats with acidosis, several other mechanisms involving glucocorticoids, insulin, and cytokines may also be important in the regulation of muscle protein balance in uremia (34-36).

In summary, our data provide evidence that the hypothalamic melanocortin system, a central signaling system for cytokines such as leptin, may play an important role in the pathogenesis of uremic cachexia. Elucidation of the mechanisms regulating appetite and metabolic rate will permit new insights into the understanding of cachexia of uremia. These findings may have significant clinical and pharmacotherapeutic implications.

\section{Methods}

Animals. All animals used in this study were on the same genetic background (C57BL/6J). C57BL/6J WT and $d b / d b$ mice were obtained from The Jackson Laboratory. C57BL/6J MC4-RKO mice were obtained from Roger Cone's laboratory. MC4-RKO mice were derived from the original C57BL/6J $\times 129$ colony (16) and were backcrossed 10 times to the $\mathrm{C} 57 \mathrm{BL} / 6 \mathrm{~J}$ strain. Homozygous MC4-RKO $/-$ mice are viable and fertile. Heterozygous $\mathrm{MC} 4-\mathrm{RKO}^{+/-}$mice were generated by mating homozygous WT and homozygous MC4-RKO-/- mice. All mice were raised grouphoused in a 12-hour light/12-hour dark cycle. For studies measuring food intake, mice were housed individually and food intake was estimated by measuring the weight of powdered food remaining in feeding chambers designed to maximize spill capture. All mice were weaned at 21 days and were either fed ad libitum or pair-fed with powdered Laboratory Rodent Diet 5015 containing $17 \%$ crude protein (LabDiet) that was weighed and replaced daily. Efficiency of food consumption was calculated as the cumulative weight gain (in grams) divided by total food consumption (in grams). Male animals, aged 8-10 weeks, were used. All studies were conducted according to the NIH Guide for the Care and Use of Laboratory Animals and were approved by the Animal Care and Use Committee of the Oregon Health and Science University.

Standard subtotal $N$ and $S$ operation. Uremia was induced in the animals by standard subtotal $\mathrm{N}$ operation, in a 1-stage procedure as previously described $(37,38)$. For each successfully $\mathrm{N}$ animal, another $\mathrm{S}$ control operation was subsequently performed in a control animal.

AGRP administration. The detailed procedure for icv cannulation was described previously (25). Briefly, WT mice were anesthetized. A small midline incision over the dorsal scalp was made to allow the access to the cranium. A sterile guide cannula with obturator stylet (Small Parts Inc.) 
was stereotaxically implanted in the lateral ventricle. The cannula was then fixed in place with dental cement (Yates \& Bird Co.). The animal was housed separately for 7 days for recovery before the subsequent operation. For cannulated animals, the correct position of the cannula was confirmed by a positive dipsogenic response to angiotensin II (Sigma-Aldrich). The correct cannula placement was also confirmed by histological examination after studies were completed, in which the animal was infused with blue dye prior to sacrifice and the brain was examined for ventricular staining. Only those animals with correctly positioned cannulae, independently assessed, were included in the study.

Each WT animal was handled daily for 3 consecutive days prior to the initiation of the experiment, simulating the restraint used during the injection of the compound. Normal saline or $2 \mathrm{nmol}$ of AGRP (84-132 amino acid fragment, a generous gift of Neurocrine Biosciences) was infused over 45 seconds in lateral ventricle-cannulated mice, using a $10-\mu \mathrm{l}$ syringe (Hamilton Co.). During 14 days of study, experimental animals were infused with either normal saline or AGRP at days $0,3,6$, 9, and 12 relative to the initial injection.

Body composition. Body composition was determined at the start and the end of the experiments by dual-energy $\mathrm{x}$-ray (DEXA) using a PIXImus mouse densitometer (MEC Lunar Corp.). The instrument was calibrated at the start of each recording session with a murine calibration standard. All animals were fasted for 12 hours before DEXA analysis to minimize the effect of ingested food.

Indirect calorimetry. Oxygen consumption and carbon dioxide production were simultaneously determined by indirect Oxymax calorimetry (Columbus Instruments). Mice were housed in separated chambers at $24 \pm 1^{\circ} \mathrm{C}$. Animals were first acclimatized to the chambers for 2 days. Measurements were recorded for 6-9 hours during the 12-hour light cycle. Samples were recorded every 3 minutes with the room air reference taken every 30 minutes; the airflow to chambers was $500 \mathrm{ml} / \mathrm{min}$. Resting metabolic rate $(\mathrm{ml} / \mathrm{kg} / \mathrm{h})$ was calculated as the average of the lowest 3 readings obtained during the recording period.

Blood chemistry analysis. After 14 days of observation, animals were sacrificed and blood samples were collected for subsequent serum chemistry analysis. BUN, serum creatinine, and blood bicarbonate levels were assayed by standard laboratory methods. Serum leptin concentrations were measured with a mouse leptin radioimmunoassay kit (Linco Research Inc.). This method detects $0.2 \mathrm{ng} / \mathrm{ml}$ leptin.

$R N A$ isolation and analysis. To measure the mRNA expression levels of various components of the ATP-dependent ubiquitin pathway, gastrocnemius muscles from experimental mice were dissected and immediately stored in RNAlater stabilization solution (Ambion) to prevent RNA degradation. Total RNA was isolated using RNeasy Midi kit (Qiagen). The quantity and purity of isolated total RNA was determined spectrophotometrically at 260 and $280 \mathrm{~nm}$. To remove potential genomic DNA contamination, total RNA sample was treated with an RNA purification kit (Roche Diagnostics).

Total RNA was reversely transcribed in 2 steps. First, $5 \mu \mathrm{M}$ oligo-d(T) ${ }_{12-18}$ (Invitrogen Corp.) was added to $1 \mu \mathrm{g}$ of total RNA, heated to $70^{\circ} \mathrm{C}$ for 10 minutes, and subsequently cooled on ice. Second, 100 units of Superscript II reverse transcriptase (Invitrogen Corp.) was added in the presence of $50 \mathrm{mM}$
DTT and $0.5 \mathrm{mM}$ deoxynucleotide triphosphate and kept at $42^{\circ} \mathrm{C}$ for 80 minutes. For every reaction set, 1 RNA sample was performed without Superscript II reverse transcriptase, serving as the negative control for the subsequent PCR amplification. To minimize variation in the reverse transcription reaction, all RNA samples from a single experimental setup were reversely transcribed using the same master mixture.

Appropriate primers and probes for mouse ubiquitin $\mathrm{C}$ and proteasome subunits C2, C3, and C9 were commercially available (Applied Biosystems). The respective Taqman Gene Expression Assays-On-Demand (Applied Biosystems) identities for mouse ubiquitin $\mathrm{C}$ and proteasome subunits $\mathrm{C} 2$, C3, and C9 were Mm01201237_m1, Mm00803741_m1,Mm00776364_mH, and $\mathrm{Mm0073710 \_ gH}$. The following Taqman probes were also used: ubiquitin C, 5' -(FAM)-ACTGCCGCCACCACCGCTGACGAT-3; C2, 5' (FAM)-ACAGAGAAAAGCACAGCCTTCACAG-3'; C3, 5' -(FAM)-GGAGTACACGCAGTCAGGTGGTGTT-3'; C9, 5'-(FAM)-ATTGCTCAACGGTACTTATTACAGT-3'. Target gene expression was related to the housekeeping gene $18 \mathrm{~S}$ ribosomal RNA. The following primers and probe for mouse $18 \mathrm{~S}$ ribosomal RNA were used: forward, 5'-CGGCTACCACATCCAAGGAA-3'; reverse, 5'-GGGCCTCGAAAGAGTCCTGT-3'; probe, 5'-(VIC)-CAGCAGGCGCGCAAATTACCCA-(TAMRA)-3' (Invitrogen Corp.). The PCR was performed in a final volume of $25 \mu \mathrm{l}$, containing $1 \mu \mathrm{l} \mathrm{cDNA}, 1.25 \mu \mathrm{l} \mathrm{Taqman}$ Gene Expression Assay for target gene, $0.3 \mu \mathrm{M}$ forward and reverse primer, $0.1 \mu \mathrm{M}$ probe (VIC) for $18 \mathrm{~S}$ ribosomal RNA, and $1 \times$ Taqman Universal Master Mix (Applied Biosystems). PCR amplification for each sample was performed in triplicate wells. The parameters for ABI Prism 7700 Sequence Detection System (Applied Biosystems) were $50^{\circ} \mathrm{C}$ for 2 minutes, $95^{\circ} \mathrm{C}$ for 10 minutes, followed by 40 cycles of $95^{\circ} \mathrm{C}$ for 15 seconds and $60^{\circ} \mathrm{C}$ for 1 minute. For all target genes and the housekeeping gene, single PCR assays were run in parallel to confirm that the cycle of threshold $\left(\mathrm{C}_{\mathrm{T}}\right)$ values were not affected by multiplex PCR amplification. Comparative $\mathrm{C}_{\mathrm{T}}$ method was used to determine the relative quantification of target gene.

Statistical analysis. Data are expressed as means \pm SD. Results were analyzed by Student's $t$ test when 2 groups were included or by 1-way ANOVA with post hoc analysis when 3 groups were included. Data sets were analyzed for statistical significance using SPSS 11.0 software package (SPSS Inc.).

\section{Acknowledgments}

The authors thank Robert Klein for technical expertise in DEXA densitometry. AGRP was kindly provided by Neurocrine Biosciences Inc. This work was supported by NIH grants R01 DK 50780 and K24 DK 059475 (to R.H. Mak) and K08 DK 62207 (to D.L. Marks).

Received for publication June 24, 2004, and accepted in revised form March 8, 2005.

Address correspondence to: Robert H. Mak, Division of Pediatric Nephrology, Department of Pediatrics, Oregon Health and Science University, 3181 South West Sam Jackson Park Road, Neuroscience Research Center 5, Portland, Oregon 97239, USA. Phone: (503) 494-6533; Fax: (503) 494-0428; E-mail: makr@ohsu.edu.
1. Kalantar-Zadeh, K., and Kopple, J.D. 2001. Relative contributions of nutrition and inflammation to clinical outcome in dialysis patients. Am. J. Kidney Dis. 38:1343-1350.

2. Guarnieri, G., Antonione, R., and Biolo, G. 2003. Mechanisms of malnutrition in uremia. J. Ren. Nutr. 13:153-157.

3. Plata-Salaman, C.R. 2001. Cytokines and feeding. Int. J. Obes. Relat. Metab. Disord. 25:S48-S52.

4. Faggioni, R., Feingold, K.R., and Grunfeld, C. 2001. Leptin regulation of the immune response and the immunodeficiency of malnutrition.
FASEB J. 15:2565-2571.

5. Grunfeld, C., et al. 1996. Endotoxin and cytokines induce expression of leptin, the $o b$ gene product, in hamsters. J. Clin. Invest. 97:2152-2157.

6. Sarraf, P., et al. 1997. Multiple cytokines and acute inflammation raise mouse leptin levels: potential role in inflammatory anorexia. J. Exp. Med. 185:171-175.

7. Sharma, K., and Considine, R.V. 1998. The Ob protein (leptin) and the kidney. Kidney Int. 53:1483-1487.

8. Banks, W.A., Kastin, A.J., Huang, W., Jaspan, J.B., and Maness, L.M. 1996. Leptin enters the brain by a saturable system independent of insulin. Peptides. 17:305-311.

9. Pinto, S., et al. 2004. Rapid rewiring of arcuate nucleus feeding circuits by leptin. Science. 304:110-115.

10. Schwartz, M.W., Woods, S.C., Porte, D., Seeley, R.J., and Baskin, D.G. 2000. Central nervous system control of food intake. Nature. 404:661-671.

11. Jacobowitz, D.M., and O'Donohue, T.L. 1978. Alpha-melanocyte stimulating hormone: immunohistochemical identification and mapping 
in neurons of rat brain. Proc. Natl. Acad. Sci. U. S. A. 75:6300-6304

12. Fan, W., Boston, B.A., Kesterson, R.A., Hruby, V.J., and Cone, R.D. 1997. Role of melanocortinergic neurons in feeding and the agouti obesity syndrome. Nature. 385:165-168.

13. Dhillo, W.S., and Bloom, S.R. 2001. Hypothalamic peptides as drug targets for obesity. Curr. Opin. Pharmacol. 1:651-655.

14. Abdel-Malek, Z.A. 2001. Melanocortin receptors: their functions and regulation by physiological agonists and antagonists. Cell Mol. Life. Sci. 58:434-441.

15. Butler, A.A., et al. 2001. Melanocortin-4 receptor is required for acute homeostatic responses to increased dietary fat. Nat. Neurosci. 4:605-611.

16. Huszar, D., et al. 1997. Targeted disruption of the melanocortin-4 receptor results in obesity in mice. Cell. 88:131-141.

17. Mizuno, T.M., et al. 1999. Fasting regulates hypothalamic neuropeptide $Y$, agouti-related peptide, and proopiomelanocortin in diabetic mice independent of changes in leptin or insulin. Endocrinology. 140:4551-4557.

18. Lawrence, C.B., and Rothwell, N.J. 2001. Anorexic but not pyrogenic actions of interleukin-1 are modulated by central melanocortin- $3 / 4$ receptors in the rat. J. Neuroendocrinol. 13:490-495.

19. Morton, G.J., and Schwartz, M.W. 2001. The NPY/ AgRP neuron and energy homeostasis. Int. J. Obes. Relat. Metab. Disord. 25:S56-S62.

20. Cowley, M.A., et al. 2003. The distribution and mechanism of action of ghrelin in the CNS demonstrates a novel hypothalamic circuit regulating energy homeostasis. Neuron. 37:649-661.

21. Williams, J., and Mobarhan, S. 2003. A critical inter- action: leptin and ghrelin. Nutr. Rev. 61:391-393.

22. Airaghi, L., et al. 2000. Plasma concentrations of alpha-melanocyte-stimulating hormone are elevated in patients on chronic haemodialysis. Nephrol. Dial. Transplant. 15:1212-1216.

23. Bald, M., Gerigk, M., and Rascher, W. 1997. Elevated plasma concentrations of neuropeptide $\mathrm{Y}$ in children and adults with chronic and terminal renal failure. Am. J. Kidney Dis. 30:23-27.

24. Yoshimoto, A., et al. 2002. Plasma ghrelin and desacyl ghrelin concentrations in renal failure. J. Am. Soc. Nephrol. 13:2748-2752.

25. Marks, D.L., Ling, N., and Cone, R.D. 2001. Role of central melanocortin system in cachexia. Cancer Res. 61:1432-1438.

26. Kotler, D.P. 2000. Cachexia. Ann. Intern. Med. 133:622-634.

27. Madiehe, A.M., Mitchell, T.D., and Harris, R.B. 2003. Hyperleptinemia and reduced TNF-alpha secretion cause resistance of $\mathrm{db} / \mathrm{db}$ mice to endotoxin. Am. J. Physiol. Regul. Integr. Comp. Physiol. 284:R763-R770.

28. Daschner, M., et al. 1998. Inappropriate elevation of serum leptin levels in children with chronic renal failure. European Study Group for Nutritional Treatment of Chronic Renal Failure in Childhood. J. Am. Soc. Nephrol. 9:1074-1079.

29. Bailey, J.L., and Mitch, W.E. 2000. Twice-told tales of metabolic acidosis, glucocorticoids, and protein wasting: what do results from rats tell us about patients with kidney disease? Semin. Dial. 13:227-231.

30. Mitch, W.E., and Goldberg, A.L. 1996. Mechanisms of muscle wasting. The role of the ubiquitin-proteasome pathway. N. Engl. J. Med. 335:1897-1905.

31. Mitch, W.E., et al. 1994 Metabolic acidosis stimu- lates muscle protein degradation by activating the adenosine triphosphate-dependent pathway involving ubiquitin and proteasomes. J. Clin. Invest. 93:2127-2133.

32. Isozaki, U., Mitch, W.E., England, B.K., and Price, S.R. 1996. Protein degradation and increased mRNAs encoding proteins of the ubiquitin-proteasome proteolytic pathway in $\mathrm{BC} 3 \mathrm{H} 1$ myocytes require an interaction between glucocorticoids and acidification. Proc. Natl. Acad. Sci. U. S. A. 93:1967-1971.

33. Baracos, V.E., DeVivo, C., Hoyle, D.H., and Goldberg, A.L. 1995. Activation of the ATP-ubiquitin-proteasome pathway in skeletal muscle of cachectic rats bearing a hepatoma. Am. J. Physiol. 268:E996-E1006.

34. Du, J., Mitch, W.E., Wang, X., and Price, S.R. 2000. Glucocorticoids induce proteasome C3 subunit expression in $\mathrm{L} 6$ muscle cells by opposing the suppression of its transcription by NF-kappa B. J. Biol. Chem. 275:19661-19666.

35. Price, S.R., et al. 1996. Muscle wasting in insulinopenic rats results from activation of the ATP-dependent, ubiquitin-proteasome proteolytic pathway by a mechanism including gene transcription. J. Clin. Invest. 98:1703-1708.

36. Mitch, W.E., Du, J., Bailey, J.L., and Price, S.R. 1999. Mechanisms causing muscle proteolysis in uremia: the influence of insulin and cytokines. Miner. Electrolyte Metab. 25:216-219.

37. Mak, R.H., and Pak, Y.K. 1996. End-organ resistance to growth hormone and IGF-I in epiphyseal chondrocytes of rats with chronic renal failure. Kidney Int. 50:400-406.

38. Mak, R.H. 1996. Insulin resistance but IGF-I sensitivity in chronic renal failure. Am. J. Physiol. 271:F114-F119. 